\title{
TÕHUSUSE TAHUD SÕJANDUSTERMINOLOOGIA NÄITEL: ÜLEDIFERENTSIMINE VÕI ERINEV TUNNETUSVÄÄRTUS?
}

\author{
Reet Hendrikson
}

Ülevaade. Artikkel käsitleb terminoloogilist eristamisvajadust: sõjanduse tekstikatkete abil otsin vastust küsimusele, kust läheb piir ülediferentsimise ja erialase mõttetäpsuse huve teeniva eristamisvajaduse vahel. Klassikalise terminiteooria põhiseisukohti on, et erialakeele toimivuse ja ühemõttelisuse tagab fikseeritud kood. Seetõttu on igasugust varieerumist kas taunitud või aktsepteeritud mööndustega ning eeldatud, et mõistete vahel on selged piirid.

Tulemustest selgub, et spetsialistide arusaamad tunnetusväärtusest ja diferentsimisvajadusest erinevad vägagi, mistõttu hägustuvad oskuskeelenähtuste piirid (nt piir sünonüümia, hüponüümia ja polüseemia vahel), tekitades terminipuntraid. Keerukate mõistesuhete puhul võib just vaste laenuandvas keeles olla spetsialistile võti mõiste tuvastamisel, kuigi praktikas on laenuandva keele eeskuju siiani sageli taunitud. Diferentsimise ja ülediferentsimise piiri leidmist komplitseerivad termini kujunemislugu ja kaasnenud mõistemuutused, samuti sotsiokultuurilised tegurid (nt võimusuhted). Ühene pole ka terminikorrastuse mõju: korrastamise nimel langetatud otsused võivad otsuse leviku algfaasis segadust juurdegi tekitada. Analüüsist järeldub, et diferentsimise ja ülediferentsimise piiri otsinguil on üldkehtivate reeglite paikapanek ebaotstarbekas. Pigem tuleks küsida, milliseid aspekte iga konkreetse otsuse puhul arvestada.

Võtmesõnad: sõjanduskeel, terminoloogia, oskuskeelekorraldus, terminivariantide eristamine, terminivariantide tunnetusväärtus, eesti keel

\section{Teoreetiline taust ja probleem}

Esmalt kolmest siinse artikli kesksest mõistest: tõhusus, ülediferentsimine ja terminivariantide tunnetusväärtus. Erialakeele tõhusust on võimalik määratleda erineval moel, kuid siinses lähtun eeldusest, et tõhusus on hea erialakeele põhilisi 
defineerivaid tunnuseid (Cabrè 1999: 47, Mereste 2000: 224, Erelt 2007: 18, Tavast 2008: 134). Kui eeldada, et erialakeele põhifunktsioone on võimalikult täpne infoedastus, siis on tõhus selline erialasuhtlus, mille puhul kõneleja (sõjanduskontekstis nt käsuandja) saavutab oma kõneteoga suhtluseesmärgi.

Tõhususe saavutamisel on oluline ühelt poolt lahus hoida mõisteid, mida pole üldkeeles tarvidust eristada. Teisalt on vähemalt sama tähtis mitte luua põhjendamatut veelahet seal, kus see pole (keeleliselt) võimalik või (erialaselt) vajalik. Niisiis seostub tõhususega järgmine märksõna - (üle)diferentsimine ehk (üle)eristamine. Ülediferentsimist on nii termini(korrastus)töödes kui teistes valdkonnakäsitlustes tavaks defineerida Mereste (2000 [1969]) järgi kui nähtust, mille puhul "püütakse teha terminoloogilist vahet selliste samatähenduslike sõnade vahel, samuti selliste sõnakujude vahel, mis keele üldseaduspärasuste põhjal tähendussisu ei muuda" (samas, 79). Sellest definitsioonist näib olevat üks oluline osa siiski puudu. Lähtudes eeldusest, et erialakeel on eeskätt erialainimese tööriist, on selle olulisimaid nõudeid funktsionaalsus just erialainimeste seisukohalt - see, et erialane suhtlustahe saaks võimalikult täpselt-tõhusalt edastatud. Kõnealust definitsiooni võiks laiendada näiteks nii: “[---] ja mille eristamise järele pole eriala(keele)s tegelikku vajadust." Mereste edasisest käsitlusest (vt samas, 79-82) võib küll oletada, et erialast, mõistelist aspekti on ehk peetud nii iseenesest mõistetavaks, et seda pole loetud tarvilikuks definitsioonis eraldi mainida. Erialases kontekstis on ometi ilmne, et vaid keeleliste näitajate põhjal määratletuna jääb kajastamata üks - ja ehk tähtsaimgi - mõistetunnus. Lähtudes defineerimise põhitõdedest peaks mõiste olulisimad tunnused siiski definitsioonis kajastuma. Iseküsimus on, kes otsustab selle vajaduse üle, aga sellest juba edaspidi.

Erialakeele kui erialainimese töövahendi viimistlemisel tuleks niisiis teada ka peamise kasutajaskonna - praegusel juhul kaitseväelaste - vaateid ja mõistestusviisi. Ohvitseride oskuskeelekäsitust uurides selgub, et nende vaated kalduvad olema äärmuslikult konservatiivsed (nt arvamus, et variatiivsusel pole sõjanduskeeles kohta, mistõttu tuleks välja kuulutada terministandard, mida kõik peavad kohustuslikus korras järgima; vt Hendrikson 2012). Seisukohavõttudest selgub, et täiseitav seisukoht igasuguse varieerumise suhtes tuleneb põhjenduse kõrval, et variandid koormavad mälu (vrd Tauli 1968: 94), sageli just ülediferentsimishirmust (vrd Erelt 2007: 117-118): kartusest, et terminivariante võidakse hakata erinevalt tõlgendama, millest johtuvad segadus ja väärmõistmine.

Ohvitserid on variatiivsusest kõneldes seega sama meelt klassikalise terminiteooriaga, mis eeldab, et iga sõna nõuab keelekasutajalt lisajõudu, millest omakorda tuleneb variatiivsuse taunimine (vt nt ISO 1999: 22, Tauli 1968: 94). Uuemad terminiteooriad, nii kommunikatiivne, sotsiokognitiivne, freimipõhine kui sotsioteooria, rõhutavad terminikasutuse sotsiaalset ja pragmaatilist aspekti: termin on keelesüsteemi dünaamiline, kontekstisõltuv osa (Cabré 1999: 112-114, Temmerman 2000: 15, Faber 2009: 114-115, 2011: 15, 25, Rey 1995: 99, 103, Gaudin 1993: 216). Temmerman (2011b: 108-109, 117) läheb veelgi kaugemale, leides, et varieerumisel on erialainimeste jaoks sageli tunnetuslik põhjus ja harva on kaalutlused puhtstilistilised. Nii võib liigne ühtlustamispüüe päädida ülestandardimisega (Bowker, Hawkins 2006: 180): sama termin võib erinevates kontekstides viidata veidi erinevatele denotaatidele (Temmerman 2000: 56 ). Teisalt ei välista Coxi ja Temmermani (2011: 6) hinnangul ka standard väärmõistmisi, kuna olulist rolli 
mängivad kultuurikontekst ja keelespetsiifilised faktorid (vrd Tavast 2012: 227). Terminivariandi tunnetusväärtuse mõiste lähtubki arusaamast, et varieerumine peegeldab tunnetuse ja kategoriseerimise mitmetahulisust: variantidel on veidi erinev tunnetuslik taust ja valik sõltub parasjagu fookuses olevast mõistenüansist (vrd Fernández-Silva jt 2011: 51-52).

Eesti oskuskeelekorralduses on traditsiooniliselt jäädud nende kahe äärmuse vahepeale. Näiteks sünonüümiast kõneldes räägib Kull (2000: 101) küll sallitavast ja suisa soovitatavast sünonüümiast, ent seegi peab olema allutatud kindlale korrapärale (vt ka Kull, Saari 1970, Saari 1980: 662, 665). Mereste (2000: 83) järgi on homonüümia ja sünonüümia teatud ulatuses vältimatud ja isegi positiivsed (kuigi teisal viitab sünonüümia halbusele, vt samas, 87). Polüseemia seevastu on Mereste (samas, 83) hinnangul läbini taunitav (vt ka Saari 1980: 662). Erelt (2007: 120) kõneleb terminivariantide erinevast stilistilisest väärtusest. Variantide juurdemõtlemisest tuleks siiski hoiduda seal, kus nende järele "ei ole tegelikku tarvidust" (samas, 123): kui mõiste tarvis on juba olemas sobiv termin või kui on tegu juhutuju või maitseotsusega. Viimane mõttekäik näib ilmselt nende jaoks, kes terminitöö praktilise poolega mingilgi moel kokku puutunud, pikemalt mõtlemata eelduspärane. Meenutades eelmainitud diferentsimisdefinitsiooni ja selle võimalikku täpsustust, tekib ometi küsimus: mis peaks olema "tegeliku tarviduse" mõõdupuu? Eeldades, et erialasuhtluses tuleb esiplaanile seada võimalikult täpne teabeedastus, siis võiksid terminivariandid justkui soositavad-soovitatavad olla - kuidas muidu oleks võimalik väljendada mõistenüansse ja oma suhtlustahet täpselt edastada?

Artikli eesmärk ongi otsida vastust küsimusele, kust läheb piir ülediferentsimise ja valdkondliku eristamisvajaduse (resp. erialainimeste tajutud tunnetusvajaduse) vahel ning milliseid aspekte tuleb otsuse tegemisel arvestada. Selleks et leida sobivad otsustuskriteeriumid, tuleb esmalt saada kõnealusest nähtusest ülevaade, viimane aga eeldab diferentsimisega külgnevate oskuskeelenähtuste käsitlemist ning uuritava materjali ja meetodi lühitutvustust.

\section{Materjal ja meetod}

Temmerman (2011b: 109-110) rõhutab, et terminivarieerumise ja selle tagamaade uurimisel on üks paremaid allikaid erialainimeste metakeelelised arutelud konkreetsete terminite sobivuse kohta. Sarnane on ka siinsete tekstikatkete valik: tegu on ohvitseridest sõjandusspetsialistide arvamusavaldustega, mis on pärit väljaõppematerjalidest, ohvitseridest magistrikursuse õppurite esseedest, magistritöödest jm. Vajadusel olen võrdluseks kasutanud ka (eriala)sõnaraamatutes esitatud andmeid. Kuna valim on väike, ei saa teha suuri üldistusi, kuid ometi on toodavad näited minu hinnangul tüüpilised, võimaldades kombata käsiteldavate mõistete piirialasid. Terminiuurija jaoks paljastavad sellised metakeelelised seisukohavõtud erialakeele selliseid tahke, mida on üsna keerukas muul moel dokumenteerida.

Originaalkujul tekstinäidetes on olulisemad ja/või kõnealused märksõnad alla joonitud. Tsitaatidele järgneb allikaviide (magistritöödel teema, esseedel kursus). 


\section{Diferentsimine ja külgnevad oskuskeelenähtused}

Et avada paremini terminoloogilise diferentsimise olemust, on kõigepealt paslik näidete varal põgusalt peatuda sellega seotud ehk külgnevatel oskuskeelenähtustel. Kõikidest neist tuleb 4. peatükis ka pikemalt juttu. Külgnevatena käsitlen olukordi, mille puhul aktualiseerub küsimus mõistete eristamisvajadusest. Võimalusi on teoreetiliselt neli (vt tabel 1).

Tabel 1. Diferentsimisega külgnevad oskuskeelenähtused

\begin{tabular}{|c|c|c|}
\hline & ÜKS MÕISTE & KAKS VÕI ENAM MÕISTET \\
\hline ÜKS TERMIN & IDEAAL & POLÜSEEMIA \\
\hline KAKS VÕI ENAM TERMINIT & SÜNONÜÜMIA & $\begin{array}{c}\text { IDEAAL VÕi } \\
\text { MÕISTESEGADIK }\end{array}$ \\
\hline
\end{tabular}

Mõiste-termini üksühene vastavus on ikka olnud terminikorrastuse (resp. klassikalise terminoloogiateooria) ideaal, ent sama seisukoht peegeldub ohvitseride arvamusavaldustes. Näiteks jalaväetaktika termineid korrastavas magistritöös (2007: 26) rõhutatakse, et sõjandusterminoloogias peab valitsema ühtsus, kuna siin on "ühtne mõistmine ja konkreetsus iseäranis oluline". Logistikatermineid korrastavas uurimuses (2009: 4) tõdetakse, et terminivariantide eristamine on sageli tarbetu ja johtub sellest, et mõistetest saadakse erinevalt aru. Ja vastupidi: kui ühe mõiste tarvis on kasutusel kaks terminit, hakatakse neid nagunii põhjendamatult eristama (Pioneeriterminid 2011: 68). Leitakse, et ühetähenduslikkuse nimel tuleb kasutada vaid üht terminit ja "see peab olema rangelt teistest eristatud" (KV MLA alg: 76). Kerge (2012: 67, 72) järgi on rangete normingute pooldamine ja keeletundlikkus eestlasele loomuomased: sageli ei mõisteta, et aeg nõuab tolerantsust rööbikute suhtes - juba ainuüksi seetõttu, et terminivariantide puhul ei pruugi maitseotsused kokku langeda.

Oskuskeelenähtuse sünonüümia all vaatlengi olukordi, mis taanduvad küsimusele, kas tegu on ikkagi samatähenduslike terminitega. Nii mõnigi kord võivad mõisted näida esmapilgul (ka definitsiooni süvenedes) kattuvatena, kuid erialainimese jaoks võib neid eristada oluline mõistetunnus või -nüanss. Mereste järgi avaldub ülediferentsimine sageli juba laenuandvas keeles ning ilmneb eeskätt suhteliselt kõrvaliste stiili-, murde- vms varjundite järeleaimamises ja teises keeles eri viisidel eluõiguse võitnud täissünonüümide eristamises (Mereste 2000: 81). Praktikas seostub mõlema aspektiga hulk aga'sid, nt millised on - erialakeele täpsustaotlust arvestades - kõrvalised stilistilised varjundid ning mil moel on täissünonüümid (?) teises keeles siiski eluõiguse võitnud? Milliste tunnuste järgi on määratletav täissünonüümia? Vaadelgem neid küsimusi esmalt näite (1) varal. Tsitaadi autor rõhutab, et taktikaterminid tiibamine ja haaramine ei tähista sama mõistet, kuigi neid on sageli samastatud.

(1) "Näiteks terminipaar tiibamine (ingl k envelopment) ja haaramine (ingl k turning movement). Esmapilgul tunduvad need sünonüümsed, kuid esimese puhul on eesmärk rünnata vastase positsioone küljelt ning teise puhul mööduda vastase positsioonidest ning liikuda sügavusse (tagalasse).” (Jalaväetaktika terminid 2007: 13) 
Kui kõrvutada eelnenud seisukohta taktikaõpikus esitatuga, ${ }^{1}$ siis selgub, et seal nähakse mõistete vahel hoopis hüponüümiat, nii et tiibamine (taktikaõpikus ingl flanking) on koos süvahaaramisega üks haaramise erivorme. Näide (1) ilmestab praktikas nii mõnigi kord ettetulevat olukorda: näilised sünonüümid võivad tähistada hoopis lähimõisteid (vrd Cruse 1986: 151) ja viidata - sageli spetsialistide erimeelsuste tõttu tekkivale - mõistesegadikule.

Niisiis on viimasel juhul tegu mitme mõiste ja mitme termini suhestumisega. Sõjanduses on levinud seisukoht, et kui tegu on erinevate mõistetega, peavad neid tähistama selgelt eristuvad keelevariandid - võimalusel erinevad tüved (vt tabeli 1 lahtreid "ideaal" ja "ideaal või mõistesegadik"). Sama seisukohta näitlikustab tekstikatke (2).

(2) "[---] mission, mis meie kontekstis omab väga spetsiifilist tähendust ning selle tõlkimine "ülesandeks" on küll lihtne ja eestimeelne, aga loob lahinguväljal sõdurite peas palju segadust, sest samuti kasutatakse sõna "task"- ülesanne-, ning lisaks on meil juba niigi olemas 'määratud ülesanded', 'kaasnevad ülesanded', 'põhiülesanne' ja veel 'võtmeülesanded'. On võimatu garanteerida, et sõjategevuse äärmuslikes tingimustes ei hakata neid omavahel sassi ajama.” (KV MLA alg: 21)

Polüseemiana vaatlen olukordi, kus erialainimeste jaoks on tegu selgelt erinevate mõistetega, aga tekib tõrge, kuna tähistajaid on üks. Mereste (2000: 87) on polüseemia suhtes kompromissitu: "Positiivset mitmetähenduslikkust pole olemas". Kõnekas on, et mõiste-termini suhteid käsitledes ei maini nt ISO 1999 (22-23) polüseemiat üldse, mõtestades seda ilmselt homonüümia alaliigina. Erelt (2007: 104) märgib ühetähenduslikkuse nõudega seoses, et iial pole raske püstitada mingeid nõudeid - raske on neid nõudeid optimaalsetes piirides rakendada. Cabrè (1999: 108) leiab, et ehkki terminoloogias on ideaal üks-mõiste-üks-termin-põhimõte, esineb tegelikkuses sellist olukorda vähe. Näide (3) on esitatud selle kohta, mis võib ohvitseride arvates juhtuda, kui mitut mõistet tähistatakse sama terminiga (siinses ülemmõiste ja üks kaasalluvatest mõistetest).

(3) "Kui näiteks rahvusvahelise väekontingendi ülem annab Eesti allüksuse ülemale informatsiooni, et naaberüksus julgestab (screen) neid, siis [---] võivad alluvad ülemad seda oluliselt erinevalt tõlgendada, kuna terminit guard võib samuti tõlkida kui julgestamistegevust. Tähenduse erinevus on siin selles, et esimesel juhul annab naaberüksus informatsiooni vastase kohta ja võitleb ainult enesekaitseks, teisel juhul saame olla kindlad, et nad võitlevad igal juhul, et anda meile aega ettevalmistamiseks. $\underline{\text { Selline situat- }}$ sioon on äärmiselt ohtlik ning võib ebasoodsate asjaolude kokkulangemisel maksta meile palju inimelusid." (2. KAKi essee)

Ohvitserid ei väsi rõhutamast, kui katastroofiliseks võib olukord osutuda, kui ei järgita termini-mõiste üksühese vastavuse põhimõtet. Samas: hoolimata sellistest, enamasti stiilis mis-siis-kui-näidetest tundub erialakeel tegelikus suhtluses ometi üldjuhul funktsioneerivat. Tavasti (2012: 227-228) järgi ei ole teada, et oleks

\footnotetext{
1 Haarama (ingl envelop) - pealetungimanööver, mille käigus põhijõud liiguvad ümber või üle vastase kaitse põhipositsioonide, et vallutada ja julgestada ründeobjekti tema tagalas (KV MLA 2010: 232).

Süvahaaramine (ingl turning movement) - haaramise erivorm, milles möödutakse või liigutakse üle vastase kaitsepositsioonidest, et vallutada ja julgestada määratud objektid vastase tagala sügavuses, ähvardades sellega nende äralõikamist, mis sunnib vastast oma positsioone maha jätma (KV MLA 2010: 247).

Tiibamine (ingl flanking) - haaramise erivorm, mille korral rünnatakse vastase positsioone küljelt, liikumata tema tagalasse (KV MLA 2010: 249).
} 
dokumenteeritud "ehtsaid [esiletõst lisatud] vääritimõistmise juhtumeid pädevate ja koostööle orienteeritud suhtlejate vahel”.

Järgmise tekstikatke (4) autor soovitab mission-task-probleemi (vt näide 2) lahendamiseks võtta sõjanduses informaatika eeskujul kasutusele sõna tegum niisiis kasutada siselaenamist (tähendusülekannet), mida klassikaline terminiteooria käsitab polüseemia erijuhuna (vt ISO 2002: 12). Katkendi autor viitab keelelise kuju ja sellest johtuvate seoste sobivusele (sh analoogia inglise terminikujuga, vt siinses artiklis ptk 4.3) ning mõistestruktuuride analoogiale (vt viimast lauset).

(4) Esialgu tundus sõna [tegum] imelik, kuid järele mõeldes tundus täitsa hea ja kohane. [---] Tegum seostub kohe tegutsemisega ning mingil määral välise sarnasuse tõttu ka inglisekeelse sõnaga task. Tegumi saab lihtsalt siduda definitsiooniga, seega [on sõna] täpne ning vaieldamatult ka lühike. Selle süsteemne kasutamine ei tekita segadust (põhi) ülesande alajaotistena: kästud, tuletatud, oluline ja võtmetegum. [---] Keeleliselt on juba olemas ka sarnane sõna - kogum ja seega alluks tegum samadel alustel ka keelereeglitele. [---] Nimelt kasutatakse Tallinna Tehnikaülikoolis juba mõnda aega õpetamisel terminit tegum ning sellele on olemas ka sarnaste seostega definitsioon." (6. KAKi essee)

Temmermani (2000: 44) järgi on polüseemia juured mõistete prototüübistruktuuris ja tähendusmuutustes - niisiis on polüseemia erialakeele funktsionaalne osa (vrd Temmerman 2002: 211, Black 1962: 37). Tavast (2002: 45-46) nendib, et kuigi ametlikult on siselaenamine tunnustatud terminisaamisviise, on praktikas seda sageli taunitud, ${ }^{2}$ põhjuseks ilmselt võõristusefekt, mis tekib sõna kasutamisel nihkunud tähenduses (vt näite (4) esimene lause). Samas on selgi küsimusel mitu tahku: ohvitserid leiavad, et juurdunud terminite kõrvale või asemele uue loomisel võib ajendiks olla muudki kui vaid püüdlemine suurema suhtlustõhususe poole (nt võimusuhted jm sotsiokultuurilised tegurid, vt näiteid (9) ja (10)).

Ilmneb, et diferentsimisega seostub rida teisi oskuskeelenähtusi, mis omakorda komplitseerib probleemi käsitlemist. Jättes kõrvale sõjandusspetsialistide seisukohad, mis ühest küljest taunivad variatiivsust, ent teisalt rõhutavad suhtlustäpsuse ja -tõhususe olulisust, jääb ikkagi alles küsimus: kuidas ja mille põhjal otsustada, kas konkreetsel juhul on tegu ülediferentsimisega või põhjendatud eristamisega, mis teenib erialase mõttetäpsuse huve?

\section{Kriteeriumiotsingud ehk kas diferentsida või mitte?}

Eelnenust ja erialastest arvamusavaldustest on tuvastatavad võimalikud kriteeriumid, mis võiks esmapilgul aidata eelmise peatüki lõpus esitatud küsimusse selgust tuua. Siinkohal käsitlen järgmisi:

- õigekeelsussõnaraamat ja kirjakeelenorming,

- erialaselt tunnetatud vajadus ning

- laenuandva keele eeskuju.

2 Selle seisukoha paikapidavust näib kinnitavat tõik, et inglise task vastena on sõjanduses senini kasutusel ülesanne. Konservatiivset joont järgis oma otsuses ka sõjandusterminoloogia komisjon (vt Militerm; nimetatud andmebaasi ja komisjoni kohta vt ka 7. joonealust märkust). 
Kindlasti on teisigi mõjureid (nt traditsioon ja isiklik harjumus), kuid järgnevad näited hõlmavad vähemalt mõningaid neist. Samas, nagu järgnevast nähtub, on kõigi nende kolmega probleeme.

\section{1. Õigekeelsussõnaraamat ja kirjakeelenorming}

Terminiaruteludes on ikka kõlanud seisukohti, et mõistete eristamisel peab olema esmakriteeriumiks õigekeelsussõnaraamat (ÕS). Kui ÕS-i järgi on kaks sõna samatähenduslikud, siis ei saavat anda neile ka oskuskeelis erinevaid tähendusi hoolimata ÕS-i saatesõnast, milles on rõhutatud, et sõnastik hõlmab eelkõige "kirjakeele kui üldrahvalikult kasutatava ja ühtseima keelekuju sõnavara”. Sellised arvamusavaldused näivad tuginevat ÕS-i funktsiooni ja laiemalt kirjakeelenormingu väärtõlgendusele. ${ }^{3}$ Kõigi erialakeelte ammendavale kirjeldamisele ÕS ju ei pretendeeri: terminoloogias tekib sageli vajadus eristada üldkeeles sünonüümsete sõnade tähendusi. Teoorias seda vajadust üldjuhul tunnetatakse ja tunnustatakse, kuid praktikas on küllalt näiteid vastupidisest. ${ }^{4}$

Sagedased on vaidlused sellegi üle, kas erialakeeles ikka võib anda sõnadele ÕS-ist erineva tähenduse. ${ }^{5}$ Teoreetilistes seisukohavõttudes küll aktsepteeritakse tähendusülekannet ja siselaenamist, kuid praktikas kaldutakse põhjendama terminivariandi mittemeeldimist väitega, et ÕS-i järgi tähendab sõna hoopis muud. Taoliste põhjenduste üldsõnalisust illustreerib hästi NATO terminitöö juhend (NATO Terminology Guidance 2007: 13). Viimase järgi on sobimatu (ingl deprecated) selline terminivariant, mis on eksitav või ebatäielik ("[---] unsuitable, for example it is misleading or incomplete"). Samas ei selgitata kuskil täpsemalt, kuidas neid omadusi tuvastada. Ebasobiva terminivariandi kirjeldamisel on selline üldsõnalisus tüüpiline: ka terminivaidlustes kasutatakse viitamist kirjakeelenormingule sageli pigem nn katteargumendina, mille taga on individuaalne maitseotsus ja tekkiv võõristusefekt. Termin, mis näib ühele erialainimesele (nt väärseoste tõttu) eksitav, ei pruugi seda olla teisele (vt ka Hendrikson 2012, Hendrikson 2013).

Ei ole läbini mõistetud, et kirjakeele sõnastik ei näe ette ega saagi ette näha kõiki kasutusjuhte ega kõigi erialakeelte vajadusi (ka Tavast 2013: 154-155). On ilmne, et oskuskeelt vaesestab kalduvus järgida mis tahes sõnaraamatut või normingut pimesi, vaid vormi tasandil, arvestamata keele siseomast ülekandevõimet. Lähtekoht võiks pigem olla erialane vajadus ja suhtlusfunktsioon. Aga nagu edasisest nähtub, ei ole needki alati ühesed.

\footnotetext{
3 Vt Eesti kirjakeele normi rakendamise kord $(\S 2 \lg 1)$ : "Kirjakeele norm on määratud Eesti Keele Instituudi uusima õigekeelsussõnaraamatuga”, ent samas paragrahvis (lg 3) seisab: "Oskussõnavara osas täiendavad ja täpsustavad kirjakeele normi oskussõnastikud [esiletõst lisatud]".

4 Näiteks esitab ÕS 2013 sõna tempo sünonüümvaste/tähendusseletuse/tähendusvihje väljal sõna kiirus ja sellest lähtudes olen kuulnud väidet, et mainitud sõnu ei tohiks ka oskuskeeles eristada. Sõjandusterminina tähistab tempo järjestikuste tegevuste rütmi ja tihedust (KV MLA 2010: 249), sõnal kiirus on sama tähendus mis üldkeeleski. On ilmne, et tähenduste eristamise on tinginud erialane vajadus.

5 Näiteks esitab ÕS 2013 sõnale kanaliseerima tähendusseletusena 'kanalisatsiooniga varustama', mistõttu ei saavat seda kasutada tähenduses 'sundima vastast liikuma kitsale maa-alale'. Samas tõestavad küsitlustulemused (Jalaväetaktika terminid 2007: 60), et termin on nimetatud mõiste tähistajana sõjanduses ilmselgelt juurdunud. Kujundlik terminikasutus võimaldab anda edasi nüansse, mis oleks muul moel raskendatud, ja aitab eristada lähimõisteid (nt siinsel juhul ei saa termin olla suunama, kuna viimane on kasutusel juba teise mõiste tähistajana; pikemalt Hendrikson 2013).
} 


\subsection{Erialaselt tunnetatud vajadus}

Erialaselt tunnetatud vajadus haakub otseselt kahe küsimusega, mis terminitöös nii mõnigi kord esile kerkivad. Esiteks: kas tegu on ikkagi terminiga? Juhul kui keelevariandid on selgelt terminid, võib osutuda küsitavaks, kas need viitavad ikkagi samale mõistele, ning kui mitte, siis milline on nende suhe. Vaadelgem mõlemat varianti näidete varal.

\subsubsection{Termin või mitte?}

Teoorias tundub termini ja üldkeele sõna vahekord olevat klaar (seda enam et ka erinevad terminiteooriad näivad olevat ses suhtes üsna ühte meelt - erinevalt nt mõiste määratlusest). Termin on mõiste/mõistmisüksuse keeleline kuju; sõna(d), millele antakse erialakeeles täpsem, piiritletud tähendus (vt nt Saari 1983: 251, ISO 1999: 22, Cabré 1999: 39, Mereste 2000: 54, Erelt 2007: 62, NATO Terminology Guidance 2007: 5-6).

Kummatigi võib praktikas vahetegemine olla päris keerukas. Sarnasele tõdemusele jõuab Kerge (2011: 111), märkides, et enamik väljendeid mõjub oskuskeelendina vaid oma stiilitunnuste tõttu (ka Erelt 2007: 69, 120, vrd Leete 2012). Cabré (1999: 80-81) leiab, et termini ja sõna erinevus saab ilmsiks, kui vaadelda termineid suhtlusüksustena. Näib niisiis, et ka keelendi n-ö terminilisuse üle otsustamisel võiks otsustusaluseks olla teoreetiliselt erialainimeste vajadus. Terminiarutelusid vaadeldes pole seegi mitte alati ühene ja selge.

Kaitseväetekstides esineb termin ülema kavatsus ${ }^{6}$ (ingl commander's intent), millega paralleelselt on kasutusel ülema tahe. Tekstikatke (5) autor väidab, et õigupoolest on tegu kahe erineva mõistega.

(5) "Ülema tahe. Saagu kohe öeldud, et siinjuures rõhutan ma sõna 'tahe', mitte kavatsus, sest ülema tahe on operatsiooni täideviimise n.ö viimane juhis, kui miski muu enam ei toimi. Aga kui ma plaanin minna päikest võtma või äkki õlut rüüpama või, mine tea, jalgpalli vaatama, siis see on kavatsus. Kavatsus on plaan, mis sisaldab endas ebakindlust ja muutlikkust, ülema tahe ent ei ole tingitav - see kuulub vastuvaidlematule järgimisele." (KV MLA alg: 64)

Kirjutaja leiab, et keelendite tunnetusväärtus on erinev, ja soovitab neid täpsust taotledes eristada. See seisukoht oli ilmselt liiga uudne ka tsiteeritud õppematerjali jaoks - miks muidu on õppematerjali lõppversioonist see lõik ära jäetud ja kasutatakse terminit ülema kavatsus? Samal kujul esineb see ka Militermis, ${ }^{7}$ ülema tahet aga terminiks ei peeta. Ometi esineb ülema tahe siiani näiteks seadusetekstis - küll vaid mõiste $k a ̈ s k$ definitsioonis (vt KVKS § 29) ja mõnes väljaõppematerjalis paralleelselt nii kavatsus kui tahe (nt Jao instruktori käsiraamat 2008: 33).

Sõjanduses esineb keelendite kõrval, mille terminiväärtuses ollakse ühte meelt, küllalt selliseid, mille terminilisus tekitab erimeelsusi. Erelt (2007: 123) leiab, et

6 Ülema kavatsus - sõjakäigu või operatsiooni soovitud eesmärkide ja lõpptulemuse saavutamise lühikirjeldus (AJP-3.2 tõlge; Militerm). Olgu lisatud, et informaalses vestluses on mitu ohvitseri olnud veendunud, et ülema kavatsus ja ülema tahe on erinevad mõisted, kuid ühelgi juhul ei osatud leida neile kahte erinevat ingliskeelset vastet (nn taandatavuskriteeriumi kohta vt ptk 4.3).

7 Sõjandusterminoloogia andmebaas Militerm on Kaitseministeeriumi sõjanduse ning julgeoleku- ja kaitsepoliitika terminoloogiakomisjoni (edaspidi sõjandusterminoloogia komisjon) töö väljund. Andmebaas sisaldab termineid alates julgeolekupoliitikast kuni sõjanduse taktikatasandini. 
terminivariantide juurdemõtlemisest tuleks hoiduda siis, kui tegu on juhutuju või maitseotsusega. Eelnenud näide illustreerib seda, et juhutuju ja maitseotsust on sageli keeruline eristada tegelikust erialasest vajadusest - juba seetõttu, et ka viimase suhtes ollakse eri seisukohtadel. Niisiis näib, et keelendi terminilisus on pigem skalaarne, mitte bipolaarne suurus ja kaksikjaotuse termin-mittetermin asemel on täpsem kõnelda pidevustikust. Põhjuseks võib olla spetsialisti(de) või terminikomisjoni käsitusviiside erinevus ja nende muutumine ajas. Neist kõigist tuleb juttu ka järgnevas alapeatükis.

\subsubsection{Kas samad mõisted või mitte?}

Kui eelmises näites taandus küsimus ühe variandi n-ö terminilisusele, siis järgnevad on komplitseeritumad. Nagu näites (3), nii tekitab ka järgmistes keerukust tõlgenduste paljusus (segadus mõistetasandil), mille lähteks on võimalik terminite hüponüümia, kasutuskontekst, kasutustraditsioon ja mõistete kujunemislugu.

Sõjanduskeeles käis kaua vaidlus, kas engagement area (EA) ja kill(ing) zone (KZ) on samaviitelised või mitte. Arvamuste paljususe illustreerimiseks olgu nimetatud seisukohti, mida olen kohanud:

1) EA on mõistemahult laiem kui KZ (viimane on seotud vaid tuletegevusega, seal ei toimu sõbralike üksuste manöövrit vastupidiselt EA-le);

2) tegu on ühe ja sama mõistega, erinevus on sõjatasandis (EA on operatsioonitasandi termin, $\mathrm{KZ}$ taktikatasandi oma);

3) $\mathrm{KZ}$ on EA vananenud variant;

4) EA on KZ-i eufemistlik variant (vrd hävitusala/tapmisala ja löögiala);

5) vaatepunkti erinevus (üks vastase, teine sõbralike üksuste vaatepunktist, vt näidet 7);

6) kasutuskonteksti erinevus (eristuse aluseks lahinguliik, vt näidet 6).

Olgu järgnevalt esitatud mõni dokumenteeritud arvamusavaldus. Näites (6) leitakse, et kasutuskonteksti erinevusest hoolimata on tegu sama mõistega, mistõttu soovitatakse tarvitada sama terminit ja loobuda sünonüümist.

(6) "Lisaks terminile engagement area on kasutusel ingliskeelne termin kill zone (FM 3-90 2001: 5-31), mis mõiste järgi samuti tähistab ala, kus toimub vastase hävitamine. FM 7-8 (1992: 2-24-b) järgi on mõiste üks, kuid varitsuse (ingl k ambush) puhul nimetatakse seda kill zone. Käesoleva töö autor arvab, et segaduste vältimiseks tuleks eesti keeles nendele kahele ingliskeelsele terminile leida ühine eestikeelne vaste." (Jalaväetaktika terminid 2007: 51)

Kontekstuaalne faktor - küll teises võtmes - on argumendiks ka näites (7), kuid siin jõutakse terminite eristamisvajaduses vastupidisele seisukohale.

(7) “Arendatav sõjanduskeel ei tohi kaotada nüansse, mille väljendamine ühe sõnaga võib vägagi raskendatud olla. Pisidetailide kadumisele võib viidata näiteks arutelu sõnade killing zone ja engagement area erinevuste üle. Tapetakse mõlemas alas, aga nüansiks on see, et ühes kavatseme seda meie teha ja teises plaanitakse meid tappa." (2. KAKi essee) 
Olgu öeldud, et samale arusaamale nagu näites (6) jõuti spetsialistide kaasabil lõpuks ka sõjandusterminoloogia komisjonis (vt Militermi kirjet hävitusala).

Teine, komplitseeritum näide (8) on sõjandusvaldkonnast, mida nimetatakse pioneerinduseks. Terminid, millest juttu tuleb, on maskeerimine ja moondamine.

(8) "Praegu käib pioneerispetsialistide seas jätkuvalt vaidlus, kumba [maskeerimine või moondamine] eelistada. [---] Kuigi nii "Pioneeritegevuse käsiraamat" kui ka V. Põder oma magistritöös "Pettetegevus ja selle rakendamine Eesti Kaitseväes" toovad välja, et tegemist on kahe erineva mõistega (maskeerimine - värvuse muutmine; moondamine - kuju ja suuruse muutmine), siis inglisekeelne terminoloogia (camouflage) neil vahet ei tee. Sama kehtib ka kasutajaskonna kohta, kes kasutavad mõlemat terminit läbisegi (maskeerimis-, moondamisvõrk; maskeerimis-, moondamisvahendid). [---] teeb autor ettepaneku kasutada kõnealuse mõiste tähistamiseks vaid terminit maskeerimine ja kaotada Militermis sünonüüm.” (Pioneeriterminid 2011: 68)

Kuigi spetsialistid on moondamise ja maskeerimise eristamisvajaduse suhtes eri meelt (vt näites (8) esitatud kõrvutavaid viiteid), arvavad mõlemad, et katustermin võiks olla pettetegevus (Pioneerindus 2010: 13, Pioneeriterminid 2011: 66-68). Viimane on nüüdseks kinnitatud üldterminina ka sõjandusterminoloogia komisjonis, maskeerimine ja moondamine selle samatähenduslike hüponüümidena. ${ }^{8}$ Moondamise ja maskeerimise samastab ka Ernits (1998), defineerides neid üldterminitena (vrd Ernits 1997, kus mõistete vahel on alluvussuhe: maskeerimine on moondamise hüperonüüm). Pettetegevus mõlemast puudub. "Pioneeritegevuse käsiraamatus" (2010: 8) on maskeerimine defineeritud taas üldterminina. Sellega kõrvuti esineb samas tähenduses, kuigi erineva definitsiooniga pettetegevus, puudub moondamine.

Kõnealusel probleemil on seega mitu tahku. Temmermani (2011b: 109) järgi on terminite varieerumisel sageli tunnetuslik tagapõhi, mistõttu võib pealtnäha samaviiteliste, näiliselt põhjuseta varieeruvate terminite taga olla erinev mõiste ja erialainimeste täpsustaotlus. Ometi nähtub, et asjatundja arvamus võib olla vaid ühe inimese isiklik, mitte valdkonnas üldaktsepteeritav seisukoht (vt ka Valdre 2012: 269). Lisaks võib terminiasenduste põhjus ohvitseride endi hinnangul olla sotsiokultuuriline, nt võimusuhted või erudeerituse näitamine (vt näiteid (9) ja (10); lähemalt Hendrikson 2012).

(9) "Pahatihti on meil liigselt võimust võtnud lapsik "pöidlajälgede vajutamise sündroom". Nii on tekkinud olukord, kus samu mõisteid nimetatakse erinevalt, mille tõttu muutub ka nende tähendus hägusaks ning mõnikord isegi vastupidiseks." (4. KAKi essee)

(10) "Väga moodne on kasutada suhtluses inglise keelseid väljendeid, et näidata ennast targemana." (3. KAKi essee)

Nagu eespool öeldud, on mõistenüansside eristamine funktsionaalne mõistagi vaid siis, kui adressaat neist nüanssidest aru saab ja (nt käsuandmissituatsioonis) vastavalt käitub. Ometi on ilmne, et klassikalisele terminoloogiateooriale omane käsitus (tähenduste täielik kattuvus versus selgepiiriline eristuvus; vt nt ISO 1999: 22) kirjeldab pigem erandolukordi kui reeglit.

8 Pettetegevus - looduslike või tehismaterjalide kasutamine isikkoosseisu, objektide või lahingupositsioonide maskeerimiseks, et vaenlast segadusse ajada, eksiteele viia või vältida (Militerm). Olgu öeldud, et 1914. aastal ilmunud "Sõjamehe sõnastikus" on mõlemat mõistet tähistatud ilusa eestikeelse terminiga sarnastama (vt Pitka 1914). 


\subsection{Taandatavus laenuandvale keelele}

Laenuandva keele moodustusmalli järgimine on tegur, mida on traditsioonilises keelekorralduses tavaks taunida ja võrdsustada teise keele kopeerimisega. Näiteks kõneleb Mereste (2000: 85, 173) kolmandasest terminituletusest (sic!), seostades seda vaid lähtumisega võõrkeelest, süvenemata mõiste olemusse. Valdre (2012: 258) leiab tehnikakeele valdkonnas, et sageli on eesmärgiks seniseid terminineid parandada, lähendades neid inglise omadele, kuid olukorda see paremaks muuta ei pruugi, kuna uued terminid lihtsalt kopeerivad teise keele väljenduslaadi ja tekitavad paralleelvariante (vt ka Erelt 2007: 213-219). Erelt tõdeb siiski, et tõlkelaenude hange ei tohi olla mehaaniline ja peab johtuma väljendusvajadusest (vt Erelt 2007: 218).

Rangelt võttes ei saa muidugi väita, nagu tähendaks või tähistaks üks sõna teist (teise keele) sõna (vrd Tavast, Taukar 2013: 62). Ometi on sageli just vaste laenuandvas keeles erialainimesele mõiste olulisim indikaator (vt ka Tavast 2002: 75, Maanso, Unt 2005). Kui tekstist avastatakse uus termin või kuuldakse seda vestluses, on vähemalt sõjanduses esimesi küsimusi sageli: kuidas see inglise keeles kõlab? On see keele allakäigu ja valdkonnakaotuse märk? Või pelgalt üks keele järjekordsetest arengujärkudest, millega tuleb tugeva liiderkeele mõjualas teatava piirini leppida - näiteks seni, kuni oma terminid on juurdunud?

Järgnev näide (11) käsitleb ühte mõistepundart, mille juures on kirjutajal olnud abi just nimelt sellest võttest. Termin on ingl main effort (ME) 'jõudude või vahendite koondamine piirkonda, kus ülem soovib saavutada lahenduse' (Militerm), mille eestikeelsete vastetena levinud paralleelvariandid on erialainimesi eksitanud: raskuspunkt, põhirõhk, põhipingutus, põhijõopingutus, peamine jõupingutus, põhipingutusüksus. Tekstidest selgub, et aja jooksul on neid hakatud tähenduslikult eristama. Olukorra teeb põnevaks asjaolu, et on ka centre of gravity (COG) 'omadused, võimed või paigad, millest tulenevad riigi, liidu, sõjajõudude või muu rühmituse tegutsemisvabadus, füüsiline jõud või võitlustahe’ (Militerm). COG-d on aga vastendatud nii terminiga raskuspunkt kui raskuskese. Niisiis on tegu näitega selle kohta, kuidas kaks mõistet on hakanud väidetavalt segi minema, kuna tähistajad on hakanud kasutuses kokku langema. Taktikaõpiku algversioonis (11) leitakse, et põhirõhk ja peamine jõupingutus tähistavad sama mõistet, ning kirjutaja argumendiks on just vastav inglise terminikuju.

(11) "Mis suhe on siis põhirõhul peamise jõupingutusega? On üsna kindel, et nad on ühetähenduslikud - tehke tagasikäik inglisekeele sõnapaarile main effort - kas on kahtlusi? Et nende paralleelsest kasutamisest tingitud segadust vältida, peame ühest neist loobuma, sest sõjalise eneseväljenduse ilu ei peitu mitte tema mitmekülgsuses, vaid ühetimõistetavuses. Niisiis teeme valiku ja käesolevast hetkest alates eelistame põhirõhku." (KV MLA alg: 76)

Jalaväetaktika termineid korrastavas magistritöös pakutakse ME vasteks aga raskuspunkt.

(12) "Lähtuvalt definitsioonist on vaste sõnastamine [inglise terminile main effort] üsna problemaatiline - see peab mahutama korraga (abstraktse) tegevustähenduse kui (konkreetse) üksuse või maa-ala tähenduse [---], 
sõna raskuspunkt [tähistab] ülekantud tähenduses tähtsaimat osa (ÕS 2006: 266, 766). Terminivariant raskuspunkt annab selgemini tähenduse edasi [kui peamine või põhijõupingutus] ning on ka ökonoomsem ja keeleliselt mugavam.” (Jalaväetaktika terminid 2007: 41)

Taktikaõpiku algversioonis (13) kõneldakse terminist raskuspunkt enesestmõistetavalt hoopis inglise COG tähenduses. Seejuures tuginetakse taas vastele laenuandnud keeles.

(13) "Nüüd aga kolmas mõiste - raskuspunkt. Tuleb tunnistada, et ka see mõiste on saanud alguse samast n.ö allikast; ilmselt on see otsetõlge saksakeelsest sõnast schwerpunkt ja nagu me eelnevalt selgeks tegime, ei peaks me enda sõjalist keelekasutust sünonüümidega risustama. Ometi ei tarvitse siinjuures prügikasti kaane avamisega kiirustada. Kui me ise suudame anda sellele mõistele uue sisulise tähenduse, millel on praktiline vajadus, ja see juurutada, siis oleme me ratsionaalselt lahendamas põhjendatud vajadust. [---] Teisisõnu - üritame jätta alles alternatiivi, millega väljendada lahingutegevuse n.ö rõhuasetust eelkõige lahingutoetusüksustele, samas eristades seda üksuse põhirõhust.” (KV MLA alg: 76)

Termini dünaamikat iseloomustab see, et nii taktikaõpiku lõppversioon (KV MLA 2010: 244) kui Militerm esitab ME kahe erineva mõistena (põhipingutus ja põhipingutusüksus), COG vasteks on aga raskuspunkt, sünonüümina raskuskese.

Niisiis on ka taandatavusel laenuandvale keelele mitmeid aga'sid. Lisaks sellele, et klammerdumine liiderkeelde võib kaasa tuua põhjendamatu teise keele matkimise ja asendada mõistekesksuse sõnakesksusega, ei pruugi ka siin olla olukord ühene erialainimeste endigi jaoks.

\section{Kokkuvõte ja järeldused}

Artikli eesmärk oli otsida vastust küsimusele, kust läheb piir terminoloogilise ülediferentsimise ja erialasest tunnetusvajadusest johtuva eristamise vahel. Sõjanduskeel on nii tõhususe kui eristamisvajaduse käsitlemisel tänuväärne uurimisobjekt: selle üldeesmärk on nagu teistelgi erialakeeltel täpne erialane teabevahetus (tegu on ühega oskuskeele allkeeltest). Samas on sõjanduskeeles iseäranis oluline see, et adressant saavutaks kõneteoga oma suhtluseesmärgi (alluv peab üksikasjaliselt aru saama, mida oodatakse, ja vastavalt tegutsema).

Ilmnes, et sissejuhatuses täiendatud diferentsimise määratlus ühest küljest küll raskendab nähtuse käsitlemist, ent teisalt aitab täpsemalt tabada selle olemust. Tõhususe poole pürgimisel on oluline arvestada võimalusega, et näilistel terminivariantidel võib olla erialainimeste jaoks erinev tunnetusväärtus, st veidi erinev tähendus(varjund). Seetõttu võib pealtnäha samaviiteliste, näiliselt põhjuseta varieeruvate terminite taga olla erinev mõiste ja erialainimeste täpsustaotlus. Samas näitavad uurimistulemused, et asjatundja arvamus võib olla vaid ühe inimese isiklik, mitte valdkonnas üldaktsepteeritav seisukoht, teiseks on arusaamad ka isikuti muutumises. Keerukust lisavad termini kujunemislugu ja sellega kaasnenud mõistemuutus(ed), samuti sotsiokultuurilised tegurid (nt võimusuhted). Pealegi on mõistenüansside eristamine tõhus ikkagi siis, kui adressaatki neid mõistab. 
Ehkki ohvitseride seas valitseb täiseitav seisukoht igasuguse variatiivsuse suhtes, tõdevad nemadki, et praktikas on olukord teistsugune. See, kuivõrd varieerumine erialasuhtluses tegelikke mõistmisraskusi tekitab, vajab veel edasist uurimist. Samuti pole ühene termini ja sõna vahekord: keelendite kõrval, mis on selgelt terminid, leidub küllalt selliseid, mille terminiväärtuses ei olda ühte meelt. Seega on keelendi terminilisus pigem skalaarne, mitte bipolaarne suurus. Triviaalsusena võib kajada tõde, et otsus keelendi terminilisuse ega mõistete eristamisvajaduse üle ei saa lähtuda vaid sõnaraamatust ega keeletasandist, kuigi samas võib laenuandnud keele terminivaste olla spetsialistile võti mõiste tuvastamisel.

Terminivariantide rohkust on peetud kujunemisjärgus eriala jooneks. See kehtib ka sõjanduse kui kiirelt ja tugeva liiderkeele mõjualas areneva valdkonna kohta. Näidetest selgus, et terminikorrastusel võib siinjuures olla ambivalentne roll: hoolimata ühtlustamis- ja segaduste vältimise taotlusest võidakse - vähemalt otsuse leviku algfaasis - segadust juurdegi tekitada. Tegu on ehk terminikorrastuse paratamatu kõrvalmõjuga, kuid siiski on oluline seda võimalust juba otsustamisel arvestada.

Ehkki eelnenud näited aitasid heita valgust diferentsimise piirialadele, näib püüe paika panna universaalseid otsustuskriteeriume ebaotstarbekas. Pigem tuleks küsida, milliseid aspekte iga konkreetse terminiotsuse puhul arvestada, ja näidete varal neid aspekte artiklis vaadeldigi. Temmerman (2011a: 56) leiab, et reaalsetes tekstides tuleb divergentsuse kui paratamatusega lihtsalt arvestada. Ühtlasi viitab ta paradoksile, et just n-ö ühtsed mõisted ongi sageli segaduste allikaks, kuna arvatakse, et nende suhtes ollakse ühte meelt.

\section{Viidatud kirjandus}

Black, Max 1962. Models and Metaphors. Ithaca: Cornell University Press.

Bowker, Lynne; Hawkins, Shane 2006. Variation in the organization of medical terms. Exploring some motivations for term choice. - Terminology, 12 (1), 79-110. http:// dx.doi.org/10.1075/term.12.1.05bow

Cabrè, Marie Teresa 1999. Terminology Theory, Methods and Applications. Amsterdam: John Benjamins. http://dx.doi.org/10.1075/tlrp.1

Cox, Antoon; Temmerman, Rita 2011. Can EU harmonisation efforts of administrative forms co-exist with cultural and linguistic diversity? - Proceedings of Conference "Languages Across Cultures" 31. Venice, 1-10.

Cruse, Alan D. 1986. Lexical Semantics. Cambridge: Cambridge University Press.

Eesti kirjakeele normi rakendamise kord. [Standard Estonian Act Implementation Act.] Riigi Teataja I 2011, 3.

Erelt, Tiiu 2007. Terminiõpetus. [Terminology.] Tartu: Tartu Ülikooli Kirjastus.

Faber, Pamela Benitez 2009. The cognitive shift in terminology and specialized translation. - África Vidal, Javier Franco (Eds.). A (Self-)Critical Perspective of Translation Theories. Monografías de Traducción e Interpretación, 1. Alicante: University of Alicante, 107-134. http://rua.ua.es/dspace/bitstream/10045/13039/1/MonTI_01_10. pdf (10.9.2013).

Faber, Pamela 2011. The dynamics of specialized knowledge representation. Simulational reconstruction or the perception-action interface. - Terminology, 17 (1), 9-29. http:// dx.doi.org/10.1075/term.17.1.02fab

Fernández-Silva, Sabela; Freixa, Judit; Cabré, M. Teresa 2011. A proposed method for analysing the dynamics of cognition through term variation. - Terminology, 17 (1), 49-73. http://dx.doi.org/10.1075/term.17.1.04fer 
Gaudin, F. 1993. Pour une socioterminologie: Des problèmes pratiques aux pra-tiques institutionnelles. Rouen: Publications de l'Université de Rouen.

Hendrikson, Reet 2012. Keelesõjas sõjakeel? Ohvitseride oskuskeelevaadetest. [Military Language at War? The Views of Officers about Military Terminology.] - Kaitseväe Ühendatud Õppeasutuste toimetised, 16, 15-39.

Hendrikson, Reet 2013. Sõjanduskeele ja kujundkeele ristteel ehk Kas kujund (oskus)keelt pigistab? [At the Crossroads of Military and Figurative Language.] - Eesti Rakenduslingvistika Ühingu aastaraamat, 9, 61-73. http://dx.doi.org/10.5128/ERYa9.04.

ISO $1999=$ Terminology work - Principles and methods. 1999. ISO/TC 37/SC 1 N. 185. Sweden: The International Organization for Standardization.

ISO 2002 = Terminoloogiatöö. Sõnastik. Osa 1. Teooria ja rakendus. [Terminology work. Vocabulary. Part 1. Theory and application.] Eesti standard EVS-ISO 1087-1:2002.

Kerge, Krista 2011. Tõlkevõhik keele- ja lugemisoskuse valdkonna terminivarast. [Translation ignorant mediating CEFR and PISA special terms.] - Peep Nemvalts (Toim.). Eesti teaduskeel ja terminikorrastus. Tallinna Ülikooli eesti keele ja kultuuri instituudi toimetised 13. Tallinn: Tallinna Ülikool, 91-114.

Kerge, Krista 2012. Keelkorraldus - kas ka täna? [Language Planning - Is It Still Actual?] Maire Raadik, Tiina Leemets (Koost. ja Toim.). Sõnaga mõeldud mõte. Pühendusteos Tiiu Ereltile 20. aprillil 2012. Tallinn: Eesti Keele Sihtasutus, 67-75.

Kull, Rein; Saari, Henn 1970. Die Entwicklung des estnischen terminologischen Gedankens und die Förderung der Fachsprachen in den letzten Jahren. - Congressus tertius internationalis Fenno-ugristarum Tallinnae habitus 17.-23. VIII 1970. Pars 1. Acta linguistica, 245-249.

Kull, Rein 2000. Kirjakeel, oskuskeel, üldkeel. [Standardised Language, Specialized Language, General Language.] Tallinn: Eesti Keele Sihtasutus.

KVKS = Kaitseväe korralduse seadus. [Estonian Defence Forces Organisation Act.] 20. märts 2013. - Riigi Teataja I, 18.

Leete, Epp 2012. Sõjandusteksti tõlgendamine NATO maaväe lahingutegevuse aluste "Allied Land Tactics" näitel. [Interpretation of a Military Text Based on the NATO Allied Land Tactic Foundations. Conference theses.] - KVÜÕA konverentsi "Sõjandustekstide tõlkimine ja tõlgendamine" ettekandeteesid. Tartu, 3.-4. mai 2012.

Maanso, Viivi; Unt, Inge (koost) 2005. Valik ülddidaktika termineid (2). Kontroll ja hindamine. [A Selection of General Didactics Terms (2). Checking and Assessment.] Tallinn: Tallinna Ülikooli Kirjastus.

Mereste, Uno 2000 [1969]. Oskuskeel ja seaduste keeleline rüü. Artikleid ja lühiuurimusi. [Specialized Language and Language of Legal Acts. Articles and short studies.] Tallinn: Eesti Keele Sihtasutus.

NATO Terminology Guidance $2007=$ Guidance for the Development and Publication of NATO Terminology. North Atlantic Council. C-M (2007) 0023.

Rey, Alain 1995. Essays on Terminology. Translated by Juan C. Sager. Amsterdam: John Benjamins. http://dx.doi.org/10.1075/btl.9

Saari, Henn 1980. Omasõna ja võõrsõna paarid eesti oskussõnavaras (1). Eelduste loomine. [Pairs of genuine and loan words in Estonian specialised language (1). Providing conditions.] - Keel ja Kirjandus, 11, 654-666; 12, 737-743.

Saari, Henn 1983. Mida nimetada terminiks? Terminoloogilisi mistselle(II). [What is a Term? Terminological remarks.] - Keel ja Kirjandus, 5, 249-252.

Tauli, Valter 1968. Keelekorralduse alused. [A Theory of Language Planning.] Stockholm: Vaba Eesti.

Tavast, Arvi 2002. Onomasioloogia ja semasioloogia vahekorrast oskuskeeles. [The relationship between onomasiology and semasiology in LSP.] Magistritöö. Juhendaja Mati Erelt. Tartu: Tartu Ülikooli eesti keele õppetool. 
Tavast, Arvi 2008. The Translator is Human Too: A Case for Instrumentalism in Multilingual Specialised Communication. Dissertationes philologiae estonicae Universitas Tartuensis 21. Tartu: Tartu University Press.

Tavast, Arvi 2012. Keelehoolde teoreetiliste aluste otsinguil: naabervaldkonnad appi. [In search of a theoretical justification for language planning: contributions from neighbouring subject fields.] - Maire Raadik, Tiina Leemets (koost ja toim). Sõnaga mõeldud mõte. Pühendusteos Tiiu Ereltile 20. aprillil 2012. Tallinn: Eesti Keele Sihtasutus, 224-234.

Tavast, Arvi; Taukar, Marju 2013. Mitmekeelne oskussuhtlus. [Multilingual specialised communication.] http://tavast.ee/public/opik/opik.pdf (1.7.2013).

Temmerman, Rita 2000. Towards New Ways of Terminology Description: the Sociocognitive Approach. Amsterdam/Philadelphia: John Benjamins. http://dx.doi.org/10.1075/ tlrp.3

Temmerman, Rita 2002. Metaphorical models and the translation of scientific texts. - Linguistica Antverpiensia, 1, 211-226.

Temmerman, Rita 2011a. Stars, problem children, dogs and cash cows: Evocative terminology in multilingual business communication. - Synaps: A Journal of Professional Communication, 25 (2), 48-61.

Temmerman, Rita 2011b. Ways of managing the dynamics of terminology in multilingual communication. - Scolia, 25, 105-122.

Valdre, Andres 2012. Tehnikakeel kui keel, mida päriselt ei osata. Eesti tehnikakeele olukord. [Technical Estonian as a poorly spoken foreign language: The situation of technical Estonian.] - Maire Raadik, Tiina Leemets (koost ja toim). Sõnaga mõeldud mõte. Pühendusteos Tiiu Ereltile 20. aprillil 2012. Tallinn: Eesti Keele Sihtasutus, 236-273.

\section{Allikad}

Ernits 1997 = Valik sõjandustermineid 1997. [Selection of Military Terms.] Koostaja Heino Ernits. Tallinn: Eesti Entsüklopeediakirjastus.

Ernits 1998 = Valimik sõjandustermineid 1998. [Selection of Military Terms.] Koostaja Heino Ernits. Tallinn: Eesti Entsüklopeediakirjastus.

Jalaväetaktika terminid 2007 = Paimla, Raigo 2007. Jalaväetaktika terminite ühtlustamine. [Infantry Tactics Terminology Harmonisation in Estonian.] Magistritöö. Juhendajad Reet Hendrikson-Pungar ja mjr Martin Herem. Tartu: Kaitseväe Ühendatud Õppeasutused.

Jao instruktori käsiraamat 2008. [Infantry Section Leader Handbook.] Võru: Kaitseväe Võru Lahingukool.

KV MLA alg = Eesti Kaitseväe maavägede lahingutegevuse alused. Maaväe ohvitseride ja staabitöö väljaõppeks. 2009. [Army Manual of the Estonian Defence Forces (draft).] Tartu: Kaitseväe Ühendatud Õppeasutused.

KV MLA 2010 = Eesti Kaitseväe maaväe lahingutegevuse alused. Maaväe ohvitseride ja staabitöö väljaõppejuhend 2010. [Army Manual of the Estonian Defence Forces.] Kaitseväe Ühendatud Õppeasutuse taktika õppetool.

Logistikaterminid 2009 = Tameri, Tarmo 2009. Eesti Kaitseväe logistikaterminoloogia korrastamine. [Logistics Terminology Harmonisation in Estonian.] Magistritöö. Juhendajad Reet Hendrikson ja kpt Erlend Zirk. Tartu: Kaitseväe Ühendatud Õppeasutused.

Militerm = Sõjandusterminoloogia andmebaas Militerm. [The Database of Military Terminology.] http://termin.eki.ee/militerm (1.10.2013).

Pioneerindus 2010 = Põder, Vesse 2010. Pettetegevus ja selle rakendamine Eesti Kaitseväes. [Deception and its Application in the Estonian Defence Forces.] Magistritöö. Juhendajad Tõnu Tomberg ja Reet Hendrikson. Tartu: Kaitseväe Ühendatud Õppeasutused. 
Pioneeritegevuse käsiraamat 2010. [Engineers Handbook.] Tallinn: Maaväe Staap. http://172.18.48.32/frame.html (1.10.2013).

Pioneeriterminid 2011 = Afanasjev, Ainar 2011. Kaitseväe pioneeriterminoloogia korrastamine. [Combat Engineering Terminology Harmonisation in Estonian.] Magistritöö. Juhendajad Reet Hendrikson ja mjr Raul Kütt. Tartu: Kaitseväe Ühendatud Õppeasutused.

Pitka 1914 = Sõjamehe sõnastik 1914. [Warrior's Vocabulary.] Irkutski polgu kapten Pitka kokkuseatud. Tallinn: G. Pihlaka raamatukaupluse kirjastus.

ÕS 2013 = Eesti õigekeelsussõnaraamat ÕS 2013. [Normative Dictionary of Estonian Language.] Toim Maire Raadik. Tallinn: Eesti Keele Sihtasutus. http://www.eki.ee/dict/ qs/ (5.2.2014).

Reet Hendrikson (Kaitseväe Ühendatud Õppeasutused, Tartu Ülikooli doktorant), peamised uurimisvaldkonnad on ilukirjanduslik ja erialane kujundkeel, sõjandusterminoloogia ning erialakeele tõhusus.

Ropka 19-13, 50111, Tartu, Eesti

reet.hendrikson@mil.ee 


\section{ASPECTS OF SPECIALISED LANGUAGE EFFICIENCY: OVER-DIFFERENTIATION OR COGNITIVE MOTIVATION?}

\section{Reet Hendrikson}

Estonian National Defence College

This article addresses terminological (over)differentiation based on military terminology. The aim of the article is to discuss the boundary between over-differentiaton and cognitively motivated term variants whose function is to ensure accurate specialised communication. The traditional view states that the functionality and unambiguity of SL (specialised language) is guaranteed by invariability of terms (established standards) and thus "unnecessary" term variants are rejected.

There are a number of other LSP (language for special purposes) topics directly associated with differentiation (e.g. synonymy, polysemy, internal loans, conceptual hotchpotch). My study has shown that officers' opinions about the necessity of differentiation vary considerably, blurring the boundaries between differentiation and over-differentiation. The changes in conceptual relations over time and the impact of sociocultural factors (e.g. power relations) both add complexity to the issue. The role of a donor language is ambivalent too: although interference is largely deprecated, in the case of complex relationships between terms, reduction to the source language often serves as a key for specialists for identifying concepts. This study suggests that attempts towards terminology harmonisation may cause even more confusion at first stage.

As current results indicate it is not functional to define generally established rules when aiming to find boundaries between differentiation and over-differentiation. Instead, we need to ask which aspects of each specific case to consider. Further research is needed to investigate the real impact of term variations in the field.

Keywords: military terminology, LSP planning, (over)differentiation of term variants, cognitive motivation, Estonian 